\title{
Selected Critical Raw Materials in Waste from Coal Gasification in Poland
}

Barbara Bielowicz (D)

check for

updates

Citation: Bielowicz, B. Selected Critical Raw Materials in Waste from Coal Gasification in Poland. Energies 2021, 14, 8071. https://doi.org/ $10.3390 /$ en14238071

Academic Editor: Dino Musmarra

Received: 25 October 2021

Accepted: 26 November 2021

Published: 2 December 2021

Publisher's Note: MDPI stays neutral with regard to jurisdictional claims in published maps and institutional affiliations.

Copyright: (C) 2021 by the author. Licensee MDPI, Basel, Switzerland. This article is an open access article distributed under the terms and conditions of the Creative Commons Attribution (CC BY) license (https:// creativecommons.org/licenses/by/ $4.0 /)$.
Faculty of Geology, Geophysics and Environment Protection, AGH University of Science and Technology, Al. Mickiewicza 30, 30-059 Kraków, Poland; bbiel@agh.edu.pl

\begin{abstract}
In an effort to identify new sources of critical raw materials (CRMs) possibility of recovering selected CRMs from Polish coals, chars, and ashes resulting from the combustion of coals and chars was investigated. The samples were collected from pilot fluidized bed gasification systems. The search for CRMs in coal gasification wastes has not been widely reported before. The study used 2 bituminous coal and 1 lignite sample; the concentration of individual critical raw materials (CRMs) was analyzed using the ICP-MS method. The obtained results were compared with Clarke values in coal ash and in the Earth's crust, and with the adopted cut-off grade. As shown by the analysis, the highest concentrations of CRMs can be found in fly ash, mainly in samples from the eastern part of the Upper Silesian Coal Basin. This applies mostly to Be, Cs, or Sb due to the fact that their concentrations were found to be higher than the Clarke value in the Earth's crust; the mentioned fly ashes could be used as potential sources of critical elements if appropriate recovery technologies are developed. In addition, the tested materials have elevated $\mathrm{Se}, \mathrm{Pb}, \mathrm{Ni}$ concentrations, but their recovery is currently not economically viable. Compared to the currently adopted cut-off grade levels, there are no critical elements in the analyzed coal gasification waste that could be recovered.
\end{abstract}

Keywords: coal gasification; coal ash; critical raw materials; rare elements; Clarke

\section{Introduction}

Because of the ever-increasing environmental degradation associated with the exploitation and use of non-renewable energy resources, work is being done on the development of environmentally friendly technologies for obtaining energy from coal. One of these technologies is the gasification of coal. The gasification process is one of the methods of extracting energy from coal and its processing. At the same time, coal gasification is considered a more environmentally friendly technology compared to conventional coal combustion [1]. The gasification process produces syngas, which is a mixture consisting primarily of carbon monoxide $(\mathrm{CO})$, hydrogen $\left(\mathrm{H}_{2}\right)$, carbon dioxide $\left(\mathrm{CO}_{2}\right)$, natural gas $\left(\mathrm{CH}_{4}\right)$, and water vapor $\left(\mathrm{H}_{2} \mathrm{O}\right)$. The gasification process includes surface gasification following the exploitation of coal and underground gasification; the process is carried out directly in the seam. The latter is not widely used due to a number of requirements related to geological, environmental, and hydrogeological conditions of underground coal gasification [2]. Gasification in reactors is carried out using several technologies, which depend on the quality of the raw material being gasified. Most currently active installations are in China, the USA, and South Africa. However, new installations are being developed around the world. Intensive work on the introduction of clean coal technologies, such as coal gasification, is also underway in Poland, where in April 2021, 51.41\% of energy came from bituminous coal and $26.91 \%$ from lignite [3]. Coal gasification and combustion processes produce fly and bottom ashes, which must be properly managed in accordance with the regulations. The current energy policy of Poland. [4] and the world is aimed at the implementation of circular economy, i.e., the best possible use of the waste generated. Due to the ever-increasing demand for various types of raw materials, it was decided to 
investigate whether the waste from gasification and combustion processes could be reused for the extraction of certain critical raw materials.

In 2008, the Committee on Critical Mineral Impacts on the US Economy introduced the term critical raw materials (CRMs). The term includes raw materials whose supply interruption would have the most harmful consequences for the economy [5]. The COVID19 crisis has prompted governments to take a critical look at the way they organize their supply chains, especially where the sources of supply of raw materials and intermediates are highly concentrated and therefore at greater risk of supply disruption. The EU, where a list of 14 critical raw materials was established in 2011, is heavily dependent on imported raw materials. The 2020 European Commission report established a group of 30 critical raw materials for strategic technologies, impacting on climate, environment, and energy, and having a specific contribution to production chains in various industries. The critical raw materials include antimony, beryllium, borates, chromium, cobalt, coking coal, fluorine, gallium, germanium, indium, magnesium, natural graphite, niobium, platinum-group metals (PGMs), phosphate rock, HREEs, LREEs, and tungsten. Such a broad list is due to the fact that China supplies $98 \%$ of the EU's rare earths, Turkey $98 \%$ of the EU's borate, and South Africa $71 \%$ of the EU's platinum and an even higher share of the platinum group metals-iridium, rhodium, and ruthenium. Figure 1 shows the dependence of the European Union on different CRM suppliers. The European Commission has presented an action plan on critical raw materials, a list of these raw materials, and forecasts for 2030 and 2050 regarding their supply and use. It proposed to diversify the supply of raw materials and to increase the efficiency of the circular economy, i.e., to recover already used raw materials such as ash and slag. The Commission also announced in its communication that it will identify, together with EU countries and individual regions, mining and processing projects that can be launched in the EU until 2025. Special emphasis is to be placed on coal mining regions and other transition regions, with particular emphasis on expertise and skills in mining, quarrying, and processing technologies.

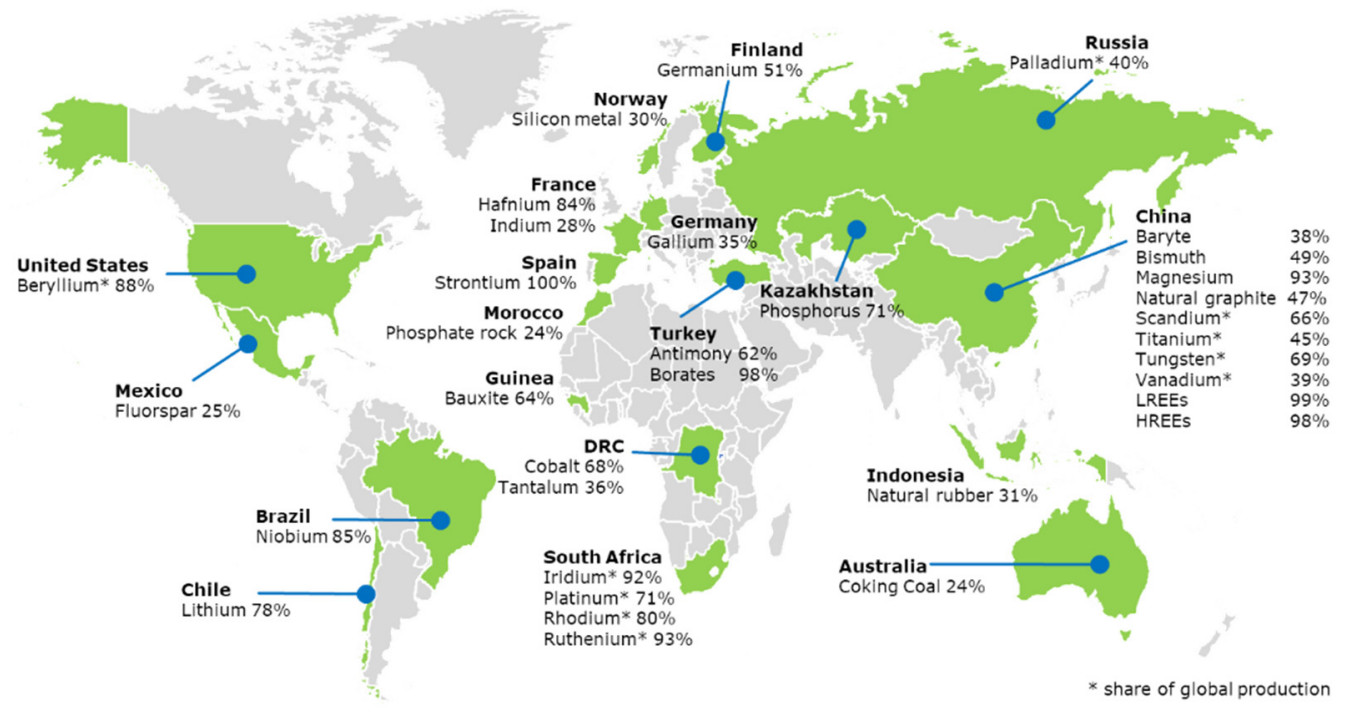

Figure 1. Major CRM suppliers to the EU Source: European Commission report on the 2020 criticality assessment [5].

The longest list, with 35 entries, entitled Final List of Critical Minerals 2018 [6] was published in the USA. This list includes, among others: arsenic, cesium, rubidium, strontium, tellurium, and uranium, which are not on the EU, Australian, and Chinese lists. Despite the fact that many critical raw materials are located in China, the National Plan for Mineral Resources (2016-2020) [7] was also introduced there in 2016. The document lists 24 strategic raw minerals, including: nickel, iron, and molybdenum. The list of Australia's Critical Minerals Strategy from 2019 [8] also has 24 critical raw materials. The critical raw 
materials on the Australian list are in line with the US list. With the increasing shortages of critical raw materials, there are ongoing efforts worldwide aimed at obtaining them from other sources. One of these sources may be waste from energy processes such as coal combustion or gasification [9-20]. With regard to individual critical raw materials, certain features, on the basis of which we can talk about the profitability of their recovery and extraction, are determined. The first step is to compare the CRM content of a given raw material to the Clark value or its average abundance in the Earth's crust. The Clarke values of individual elements in coal and its ashes were determined by Ketris and Yudovich [21]. The cut off grade [22] was used to assess the effectiveness and profitability of CRM recovery. According to Seredin and Finkelman [23], CRM recovery from coal and ash is economically viable when their concentrations are at least 10 times higher than the corresponding averages for world coals. Already now Ge, U, V, and Se, which are extracted from coal, are used industrially in China [24,25]. To increase the supply mix of these elements, work is also being carried out in Poland on the recovery of critical raw materials from ash produced during coal combustion and gasification.

The article discusses the possibility of recovery of CRMs from Polish coal. The primary focus was on coal gasification by-products such as char and ash. Char and fly and bottom ashes obtained during the combustion of coal and chars from three deposits (1 lignite and 2 bituminous coal deposits) were analyzed in order to determine the potential for management of the resulting waste. The analysis of the possibility of using waste as a raw material for recovery of critical raw materials is important from the point of view of circular economy and rational management of deposits. In addition, the determination of the chemical composition makes it possible to establish the guidelines for the disposal of toxic substances in the waste generated. The presented study on the content of CRMs in the resulting waste and the obtained results are unique due to the ongoing work on the application of the coal gasification process carried out in Poland. This is of great importance due to the fact that already at the stage of the demonstration plant it is necessary to establish the guidelines for the disposal of the resulting ash and char. Moreover, the search for CRMs in gasification wastes is not discussed in detail in the literature. Hence, the present article fills this gap.

\section{Samples and Research Methodology}

The analysis was based on coal samples from three Polish deposits: 2 samples from the Upper Silesian Coal Basin located in southern Poland and 1 sample from the Bełchatów field (central Poland). A channel sample was collected from the deposits in accordance with the applicable standards. The proximate and ultimate analyses of output samples are presented in Table 1. The analysis was performed in accordance with the applicable standards (Table 1). The coal sample was divided into two parts. The first was gasified and then burned; the second was subjected to combustion process. Test samples were obtained during gasification experiments in a pilot installation at the Institute for Chemical Processing of Coal in Zabrze, Poland. A circulating fluidized bed (CFB) reactor with $\mathrm{CO}_{2}$ as the gasifying agent was used for the production of syngas. During the tests, the gasification temperature was $850-1100{ }^{\circ} \mathrm{C}$.

Table 1. Results of proximate and ultimate analyses of coal samples.

\begin{tabular}{ccccccc}
\hline Parameter & Symbol & Norm & Unit & 1C & 2C & 3C \\
\hline Moisture & $\mathrm{M}^{\mathrm{dd}}$ & ISO 589:2008 [26] & $\%$ & 5.30 & 3.6 & 50.3 \\
Ash & $\mathrm{A}^{\mathrm{db}}$ & ISO 1171:2010 [27] & $\%$ & 13.80 & 8.2 & 23.6 \\
Volatile matter & $\mathrm{V}^{\text {daf }}$ & ISO 562:2010 [28] & $\%$ & 38.20 & 35.3 & 58.59 \\
Gross calorific value & $\mathrm{GCV}^{\text {daf }}$ & ISO 1928:2020[29] & $\mathrm{MJ} / \mathrm{kg}$ & 31.50 & 33.2 & 18.1 \\
Carbon content & $\mathrm{C}_{\mathrm{t}}{ }^{d a f}$ & ISO 29541:2010 [30] & $\%$ & 79.93 & 81 & 62.2 \\
Hydrogen content & $\mathrm{H}_{\mathrm{t}}{ }^{d a f}$ & ISO 29541:2010 [30] & $\%$ & 5.14 & 4.5 & 3.74 \\
Nitrogen content & $\mathrm{N}^{\text {daf }}$ & ISO 29541:2010 [30] & $\%$ & 1.30 & 1.2 & 0.52 \\
\hline
\end{tabular}


Table 1. Cont.

\begin{tabular}{ccccccc}
\hline Parameter & Symbol & Norm & Unit & 1C & 2C & 3C \\
\hline Total sulfur & $\mathrm{S}_{\mathrm{t}} \mathrm{db}$ & ISO 19579:2006 [31] & $\%$ & 1.39 & 0.42 & 0.84 \\
Random reflectance & $\mathrm{R}$ & ISO 7404-5:1994 [32] & $\%$ & 0.45 & 0.77 & 0.26 \\
Vitrinite/Huminite group & $\mathrm{V}$ & ISO 7404-3:2009 [33] & $\%$ & 51 & 60.96 & 81.72 \\
Liptinite group & $\mathrm{L}$ & ISO 7404-3:2009 [33] & $\%$ & 8 & 4.83 & 7.02 \\
Inertinite group & $\mathrm{I}$ & ISO 7404-3:2009 [33] & $\%$ & 36 & 28.97 & 3.57 \\
Mineral Matter & $\mathrm{MM}$ & ISO 7404-3:2009 [33] & $\%$ & 5 & 5.23 & 7.7 \\
\hline ad—air dried, db-dry basis, daf-dry, ash free basis.
\end{tabular}

A detailed description of coal gasification has already been given [34,35]. The gasification residues formed during gasification were burned. In addition, coal samples were also burned. The combustion process was performed in a facility located at the Czestochowa University of Technology. The coal and gasification residues were subjected to combustion using CFB technology. The experimental installation for the combustion of coal and char has already been discussed [36]. During the process, two types of ash were generated in the boiler. Bottom ash, which settles at the bottom of the boiler, and fly ash particles carried by the air current. The combustion of chars was carried out at a temperature of approximately $780-875^{\circ} \mathrm{C}$, with a fuel flow ranging from $2 \mathrm{~kg} / \mathrm{h}$ to $3.2 \mathrm{~kg} / \mathrm{h}$ and a $\lambda$ from 1.09 to 1.93 . Coal $\left(3-7 \mathrm{~kg} / \mathrm{h}\right.$ ) was burned at atmospheric pressure at a temperature of $750-900^{\circ} \mathrm{C}$. All samples were burned in a fluidized bed. This enabled to reduce the combustion temperature (to $\left.800-900{ }^{\circ} \mathrm{C}\right)$, combustion chamber dimensions, and allowed the use of inferior quality fuels (contaminated, with lower calorific value). A total 18 samples were used in the CRM content analysis: 3 coal samples, 3 char samples, 3 fly ash samples from coal combustion, 3 bottom ash samples from coal combustion, 3 fly ash samples from char combustion, and 3 bottom ash samples from char combustion.

The sample no. 1 is bituminous coal, which, according to the nomenclature, is on the border of low-rank and medium-rank coal in terms of the degree of coalification. The sample no. 2 is medium-rank coal and sample no. 3 is lignite. The sample no. 1 is from the eastern part and sample no. 2 is from the northern part of the Upper Silesian Coal Basin (USCB).

The analysis of the chemical composition of ash and the elemental composition of coals, chars, and ashes was performed by the accredited laboratory (The Bureau Veritas Minerals Laboratory). The ICP-MS analysis was caried out on a sample after modified aqua regia digestion $\left(1: 1: 1 \mathrm{HNO}_{3}: \mathrm{HCl}: \mathrm{H}_{2} \mathrm{O}\right)$ for low to ultra-low determination of both coal and ash.

In total, the content of 56 elements was analyzed. Table 2 gives the detection limit for each element. In some samples, the content of some elements was below this value.

Table 2. Critical raw materials in coal, chars, and ashes.

\begin{tabular}{|c|c|c|c|c|c|c|c|c|c|c|}
\hline Sample & $\mathrm{Ag}$ & As & $\mathrm{Be}$ & $\mathbf{B i}$ & Co & $\mathrm{Cr}$ & Cs & $\mathrm{Cu}$ & $\mathrm{Ga}$ & $\mathrm{Ge}$ \\
\hline $1 \mathrm{C}$ & 0.1 & 4.6 & 4.0 & 0.3 & 4.7 & 11.3 & 2.1 & 15.1 & 1.9 & 0.2 \\
\hline $1 \mathrm{Ch}$ & 0.1 & 1.3 & 1.2 & 0.1 & 3.4 & 16.6 & 3.2 & 17.1 & 2.0 & 0.1 \\
\hline $1 \mathrm{CBA}$ & 0.1 & 9.9 & 4.0 & 0.6 & 6.1 & 24.9 & 7.2 & 25.4 & 7.2 & 0.3 \\
\hline 1CFA & 0.3 & 18.6 & 26.2 & 1.5 & 25.5 & 65.7 & 19.2 & 66.2 & 22.1 & 0.8 \\
\hline $1 \mathrm{ChBA}$ & 0.3 & 24.0 & 4.8 & 0.8 & 11.7 & 46.9 & 31.1 & 94.0 & 25.3 & 0.1 \\
\hline 1ChFA & 0.4 & 13.3 & 29.7 & 0.3 & 31.0 & 82.4 & 18.2 & 74.0 & 26.2 & 0.9 \\
\hline $2 \mathrm{C}$ & 0.0 & 0.2 & 0.5 & 0.1 & 1.4 & 1.8 & 0.4 & 5.6 & 0.1 & 0.3 \\
\hline $2 \mathrm{Ch}$ & 0.0 & 0.8 & 0.5 & 0.1 & 2.2 & 13.2 & 1.2 & 16.6 & 1.4 & 0.1 \\
\hline $2 \mathrm{CBA}$ & 0.1 & 3.0 & 1.6 & 0.3 & 7.0 & 23.6 & 2.9 & 26.6 & 5.2 & 0.4 \\
\hline 2CFA & 0.2 & 7.6 & 7.9 & 0.6 & 15.3 & 56.0 & 5.7 & 52.8 & 9.6 & 1.0 \\
\hline 2ChBA & 0.1 & 1.7 & 1.6 & 0.2 & 6.9 & 42.6 & 4.0 & 23.3 & 6.4 & 0.1 \\
\hline
\end{tabular}


Table 2. Cont.

\begin{tabular}{|c|c|c|c|c|c|c|c|c|c|c|}
\hline Sample & Ag & As & $\mathrm{Be}$ & $\mathbf{B i}$ & Co & $\mathrm{Cr}$ & Cs & $\mathrm{Cu}$ & Ga & $\mathrm{Ge}$ \\
\hline 2ChFA & 0.2 & 2.6 & 3.8 & 0.3 & 15.0 & 40.4 & 5.4 & 58.5 & 7.9 & 0.8 \\
\hline $3 C$ & 0.0 & 0.5 & 0.3 & 0.1 & 0.7 & 7.5 & 0.1 & 4.7 & 1.0 & 0.2 \\
\hline $3 \mathrm{Ch}$ & 0.1 & 1.2 & 0.7 & 0.0 & 1.7 & 22.5 & 0.7 & 14.3 & 4.1 & 0.4 \\
\hline $3 \mathrm{CBA}$ & 0.1 & 5.6 & 1.9 & 0.8 & 5.5 & 31.8 & 1.6 & 22.0 & 5.2 & 0.5 \\
\hline 3CFA & 0.1 & 6.1 & 2.3 & 0.5 & 5.7 & 76.1 & 1.5 & 32.2 & 15.6 & 0.8 \\
\hline 3ChBA & 0.2 & 4.7 & 1.8 & 0.3 & 7.3 & 52.5 & 3.2 & 31.3 & 10.3 & 0.4 \\
\hline 3ChFA & 0.2 & 9.9 & 2.8 & 0.1 & 8.4 & 82.1 & 1.7 & 49.3 & 17.8 & 1.0 \\
\hline Low-rank coals [21] & 0.1 & 7.6 & 1.2 & 0.8 & 4.2 & 15.0 & 1.0 & 15.0 & 5.5 & 2.0 \\
\hline Hard coals [21] & 0.1 & 9.0 & 2.0 & 1.1 & 6.0 & 17.0 & 1.1 & 16.0 & 6.0 & 2.4 \\
\hline All coals [21] & 0.1 & 8.3 & 1.6 & 1.0 & 5.1 & 16.0 & 1.0 & 16.0 & 5.8 & 2.2 \\
\hline Low-rank coal ash [21] & 0.6 & 48.0 & 6.7 & 4.3 & 26.0 & 82.0 & 5.2 & 74.0 & 29.0 & 11.0 \\
\hline Hard coal ash [21] & 0.6 & 46.0 & 12.0 & 7.5 & 37.0 & 120.0 & 8.0 & 110.0 & 36.0 & 18.0 \\
\hline Total; coal ash [21] & 0.6 & 47.0 & 9.4 & 5.9 & 32.0 & 100.0 & 6.6 & 92.0 & 33.0 & 15.0 \\
\hline Suggested cut-off grade [37] & 10 & - & 300 & - & - & - & 150 & - & 100 & 300 \\
\hline Earth's crust & 0.1 & 2.1 & 1.9 & 0.0 & 30.0 & 140.0 & 1.9 & 68.0 & 19.0 & 1.4 \\
\hline Sample & Hf & In & $\mathbf{L i}$ & Mn & Mo & $\mathrm{Nb}$ & $\mathrm{Ni}$ & $\mathbf{P b}$ & $\mathbf{R b}$ & $\mathrm{Sb}$ \\
\hline $1 \mathrm{C}$ & 0.1 & 0.0 & 3.6 & 100 & 0.8 & 0.5 & 13.9 & 26.3 & 6.0 & 0.6 \\
\hline $1 \mathrm{Ch}$ & 0.1 & 0.0 & 17.8 & 143 & 1.1 & 0.1 & 11.4 & 22.5 & 13.5 & 0.4 \\
\hline $1 \mathrm{CBA}$ & 0.2 & 0.1 & 26.7 & 205 & 2.5 & 0.1 & 41.6 & 73.3 & 32.9 & 5.8 \\
\hline 1CFA & 0.8 & 0.2 & 86.9 & 240 & 10.1 & 0.3 & 141.4 & 130.8 & 78.0 & 7.0 \\
\hline $1 \mathrm{ChBA}$ & 0.2 & 0.1 & 72.0 & 712 & 2.9 & 0.0 & 65.2 & 82.1 & 102.8 & 4.0 \\
\hline 1ChFA & 1.1 & 0.1 & 96.0 & 483 & 11.2 & 0.7 & 99.6 & 104.5 & 74.4 & 9.6 \\
\hline $2 \mathrm{C}$ & 0.0 & 0.0 & 1.1 & 273 & 0.2 & 0.1 & 7.1 & 9.8 & 1.6 & 0.1 \\
\hline $2 \mathrm{Ch}$ & 0.1 & 0.0 & 9.5 & 357 & 0.6 & 0.1 & 8.0 & 13.0 & 7.6 & 0.4 \\
\hline $2 \mathrm{CBA}$ & 0.2 & 0.0 & 15.7 & 1143 & 1.6 & 0.1 & 64.9 & 26.5 & 19.4 & 2.0 \\
\hline 2CFA & 0.6 & 0.1 & 43.5 & 986 & 7.2 & 0.7 & 98.1 & 65.4 & 33.1 & 5.9 \\
\hline 2ChBA & 0.2 & 0.0 & 21.2 & 1259 & 1.6 & 0.1 & 44.9 & 29.4 & 30.4 & 1.2 \\
\hline 2ChFA & 0.4 & 0.0 & 52.2 & 1015 & 4.1 & 0.6 & 67.9 & 86.4 & 31.3 & 4.8 \\
\hline $3 C$ & 0.1 & 0.0 & 0.5 & 46 & 0.3 & 0.4 & 3.1 & 3.4 & 0.6 & 0.1 \\
\hline $3 \mathrm{Ch}$ & 0.4 & 0.0 & 6.7 & 165 & 1.1 & 0.5 & 9.1 & 8.5 & 4.0 & 0.2 \\
\hline $3 \mathrm{CBA}$ & 0.3 & 0.1 & 10.5 & 183 & 3.3 & 0.4 & 132.3 & 31.8 & 10.6 & 1.8 \\
\hline 3CFA & 1.6 & 0.1 & 14.6 & 264 & 6.5 & 0.6 & 44.2 & 31.2 & 7.6 & 1.3 \\
\hline 3ChBA & 0.5 & 0.1 & 22.4 & 670 & 3.8 & 0.2 & 57.9 & 43.6 & 20.3 & 1.7 \\
\hline 3ChFA & 1.9 & 0.1 & 21.7 & 564 & 7.1 & 0.4 & 45.8 & 17.5 & 9.2 & 2.6 \\
\hline Low-rank coals [21] & 1.2 & 0.0 & 10.0 & 100 & 2.2 & 3.3 & 9.0 & 6.6 & 10.0 & 0.8 \\
\hline Hard coals [21] & 1.2 & 0.0 & 14.0 & 71 & 2.1 & 4.0 & 17.0 & 9.0 & 18.0 & 1.0 \\
\hline All coals [21] & 1.2 & 0.0 & 12.0 & 86 & 2.2 & 3.7 & 13.0 & 7.8 & 14.0 & 0.9 \\
\hline Low-rank coal ash [21] & 7.5 & 0.1 & 49.0 & 550 & 15.0 & 18.0 & 52.0 & 38.0 & 48.0 & 5.0 \\
\hline Hard coal ash [21] & 9.0 & 0.2 & 82.0 & 430 & 14.0 & 22.0 & 100.0 & 55.0 & 110.0 & 7.5 \\
\hline Total; coal ash [21] & 8.3 & 0.2 & 66.0 & 490 & 14.0 & 20.0 & 76.0 & 47.0 & 79.0 & 6.3 \\
\hline Suggested cut-off grade [37] & - & - & - & - & 1000 & 300 & - & - & - & 1000 \\
\hline Earth's crust & 3.3 & 0.2 & 17.0 & 1100 & 1.1 & 17.0 & 90.0 & 10.0 & 60.0 & 0.2 \\
\hline Sample & Sc & Se & Sn & Sr & $\mathbf{V}$ & W & $\mathbf{Y}$ & Zn & $\mathrm{Zr}$ & REE \\
\hline $1 \mathrm{C}$ & 2.1 & 1.0 & 0.7 & 27.7 & 23 & 0.4 & 4.9 & 100.2 & 2.2 & 25.8 \\
\hline $1 \mathrm{Ch}$ & 1.4 & 0.5 & 0.5 & 31.3 & 13 & 0.2 & 2.2 & 67.4 & 1.7 & 32.0 \\
\hline $1 \mathrm{CBA}$ & 3.9 & 0.3 & 3.7 & 42.6 & 34 & 0.4 & 6.8 & 99.2 & 8.0 & 98.7 \\
\hline 1CFA & 15.1 & 2.8 & 4.9 & 163.5 & 151 & 2.3 & 33.4 & 162.1 & 33.8 & 225.3 \\
\hline 1ChBA & 7.2 & 0.2 & 7.7 & 120.8 & 58 & 0.3 & 12.6 & 117.2 & 7.1 & 227.7 \\
\hline 1ChFA & 20.0 & 4.7 & 3.4 & 293.9 & 201 & 3.1 & 44.4 & 208.7 & 42.7 & 259.4 \\
\hline $2 \mathrm{C}$ & 0.4 & 0.8 & 0.1 & 24.8 & 2 & 0.1 & 0.8 & 12.8 & 0.5 & 5.9 \\
\hline $2 \mathrm{Ch}$ & 1.0 & 0.8 & 0.4 & 28.7 & 6 & 0.1 & 1.3 & 29.8 & 1.3 & 23.0 \\
\hline
\end{tabular}


Table 2. Cont.

\begin{tabular}{|c|c|c|c|c|c|c|c|c|c|c|}
\hline Sample & Sc & Se & Sn & $\mathrm{Sr}$ & V & W & $\mathbf{Y}$ & $\mathrm{Zn}$ & $\mathrm{Zr}$ & REE \\
\hline $2 \mathrm{CBA}$ & 3.3 & 0.3 & 1.5 & 75.0 & 24 & 0.2 & 4.7 & 66.7 & 6.2 & 62.0 \\
\hline 2CFA & 7.7 & 12.1 & 2.3 & 279.8 & 69 & 1.2 & 17.5 & 102.2 & 21.2 & 118.8 \\
\hline $2 \mathrm{ChBA}$ & 4.1 & 0.5 & 1.5 & 80.3 & 29 & 0.2 & 4.5 & 76.7 & 5.4 & 68.9 \\
\hline 2ChFA & 5.5 & 9.7 & 1.7 & 295.2 & 50 & 0.6 & 10.0 & 147.6 & 12.5 & 91.2 \\
\hline $3 C$ & 1.5 & 1.5 & 0.3 & 247.2 & 9 & 0.1 & 2.2 & 13.2 & 1.5 & 17.9 \\
\hline $3 \mathrm{Ch}$ & 3.9 & 4.3 & 1.0 & 653.6 & 24 & 0.2 & 5.9 & 36.8 & 10.8 & 60.1 \\
\hline $3 \mathrm{CBA}$ & 3.2 & 0.3 & 2.2 & 192.9 & 23 & 0.5 & 6.7 & 91.2 & 11.6 & 59.9 \\
\hline 3CFA & 12.5 & 16.1 & 3.5 & 1874.6 & 88 & 0.9 & 22.1 & 51.9 & 61.6 & 197.3 \\
\hline $3 \mathrm{ChBA}$ & 7.1 & 1.0 & 2.3 & 448.8 & 51 & 0.4 & 10.1 & 113.4 & 18.0 & 112.4 \\
\hline 3ChFA & 16.0 & 20.7 & 4.9 & $>2000.0$ & 115 & 1.1 & 28.2 & 92.8 & 78.2 & 241.7 \\
\hline Low-rank coals [21] & 4.1 & 1.0 & 0.8 & 120.0 & 22 & 1.2 & 8.6 & 18.0 & 35.0 & 78.7 \\
\hline Hard coals [21] & 3.7 & 1.6 & 1.4 & 100.0 & 28 & 1.0 & 8.2 & 28.0 & 36.0 & 82.5 \\
\hline All coals [21] & 3.9 & 1.3 & 1.1 & 110.0 & 25 & 1.1 & 8.4 & 23.0 & 36.0 & 82.6 \\
\hline Low-rank coal ash [21] & 23.0 & 7.6 & 4.7 & 740.0 & 140 & 6.0 & 44.0 & 110.0 & 190.0 & 429.0 \\
\hline Hard coal ash [21] & 24.0 & 10.0 & 8.0 & 730.0 & 170 & 7.8 & 57.0 & 170.0 & 230.0 & 537.0 \\
\hline Total coal ash [21] & 23.0 & 8.8 & 6.4 & 740.0 & 155 & 6.9 & 51.0 & 140.0 & 210.0 & 485.0 \\
\hline Suggested cut-off grade [37] & - & 100 & 500 & - & - & 1000 & 1000 & 300 & - & 2000 \\
\hline Earth's crust & 26.0 & 0.1 & 2.2 & 360.0 & 190 & 1.1 & & 79.0 & 160.0 & 144.3 \\
\hline
\end{tabular}

The concentration of selected critical raw materials in the above-mentioned 18 samples was compared with their abundance in the Earth's crust, the Clarke value in coal and ashes, and with the cut-off grade.

\section{Results and Discussion}

Of the 56 elements analyzed, the critical raw materials whose concentrations in the analyzed samples were above the minimum detection limit were selected (Supplementary Materials).

As a consequence, the data for $\mathrm{Au}, \mathrm{Ta}, \mathrm{Pt}$, and $\mathrm{Pd}$ were rejected, as their concentration in the tested samples was below the detection limit (Table 2). Subsequently, the detailed description of the critical raw materials for which no Clarke value has been calculated, even though they are present in large amounts in coal and its ashes, is omitted. Therefore, the concentrations of $\mathrm{Al}, \mathrm{Fe}, \mathrm{K}, \mathrm{Mg}$, and Ti were only mentioned in Supplementary Materials without further comment. The presented graphs are own work based on the obtained research results and literature data on Clarke values in coal and ash and the content in the Earth's crust.

As a result, 29 critical raw materials + REE were included in the analysis (Table 2).

The lowest (of the ppb order) concentrations of the analyzed critical raw materials were observed for silver $(A g)$ and indium (In). Indium is an important raw material for the production of semiconductors and is used in the electronics industry, particularly in the production of LCD displays and solar panels. Therefore, this material is one of the most sought after. In coal its Clarke value is $0.031 \mathrm{ppm}$, and in ashes it is $0.16 \mathrm{ppm}$. Its concentration is similar to its concentration in the Earth's crust. The indium content in the tested samples is the highest in the fly ash from sample 1 . However, it is well below the Clarke value in ash (Figure 2, Table 2). For comparison, in Bulgarian deposits, these concentrations are higher and range from 0.002 to $0.167 \mathrm{ppm}$ in coal and from 0.005 to $0.57 \mathrm{ppm}$ in the ash [38]. While the cut-off grade for In is not determined in the literature, it can be stated that the above-mentioned Indium concentrations in coal and ash are unsatisfactory from an economic point of view. Similar conclusions were also reached by Dai and Finkelman [37], who concluded that the recovery of In from coal or coal ash is not economically viable.

In addition, the $\mathrm{Ag}$ concentration in the tested samples is low and does not have economic potential (Figure 2, Table 2). However, in other deposits and ashes, it may be 
highly-promising for utilization, as extraction technologies are currently on laboratory scale or are currently being optimized for further development towards pilot scale [37].

0.7

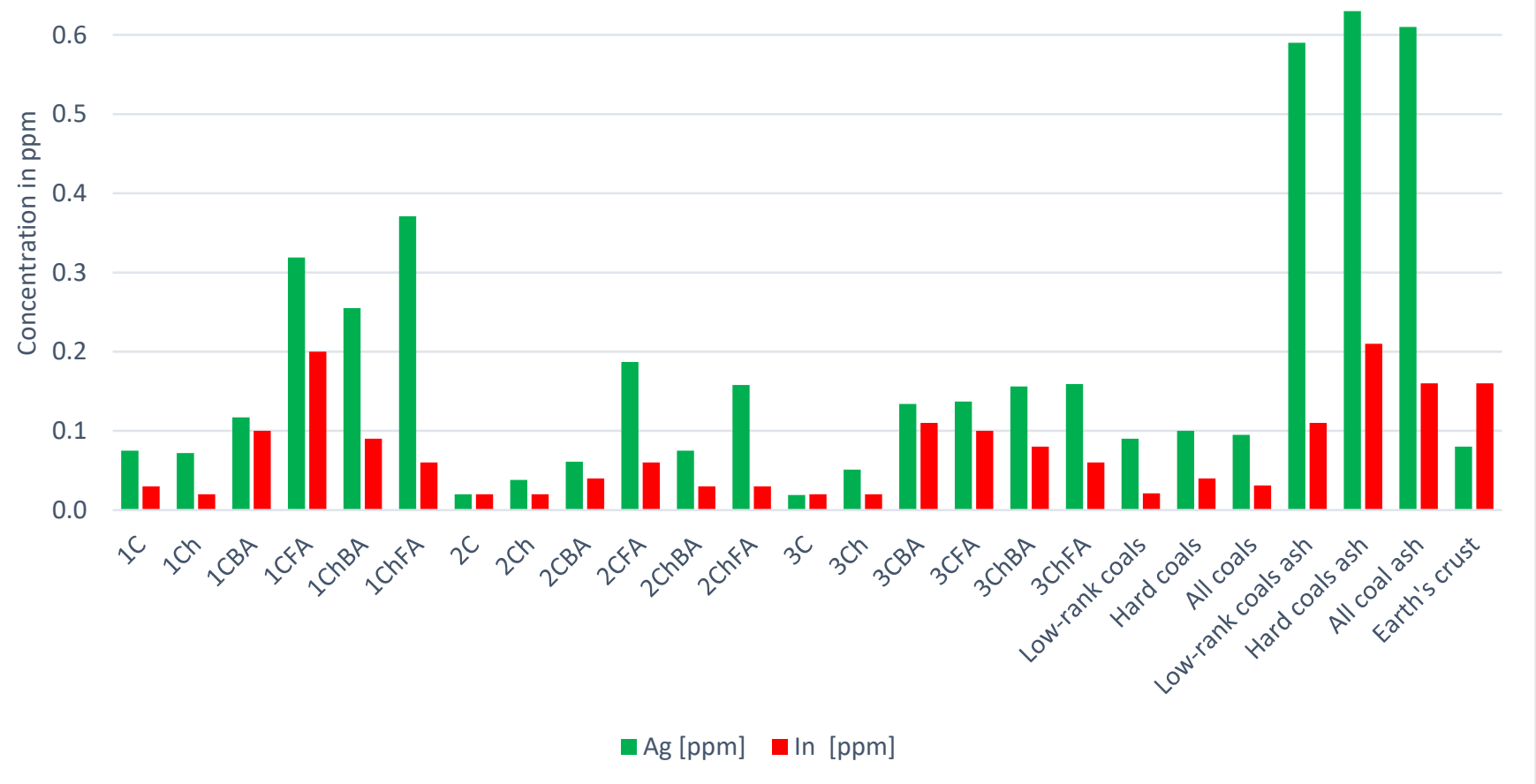

Figure 2. The Ag and In content of coal, char, and ashes and their Clarke values [21].

For example, such elements as bismuth (Bi), chromium (Cr), cuprum (Cu), germanium $(\mathrm{Ge})$, hafnium $(\mathrm{H} f)$, niobium $(\mathrm{Nb})$ tungsten $(\mathrm{W})$, and yttrium $(\mathrm{Y})$ are some of the most sought-after raw materials, as they are widely used in modern technologies. Germanium is one of those elements that can be concentrated in coal deposits [39-41] and in ashes from gasification processes [42,43]. It is also recovered from the high-Ge coal deposits in Inner Mongolia [44] and residues from gasification processes. [45,46]. In recent years it has been shown that world-class Ge deposits result from the interaction of hydrothermal fluids with organic matter in coal seams [41]. Unfortunately, in the tested samples, the Ge concentrations are below the Clarke value for coal and the Earth's crust (Figure 3). The concentrations of $\mathrm{Bi}, \mathrm{Hf}$ (Figure 3), W, Zr (Figure 4), $\mathrm{Nb}$ (Figure 5), $\mathrm{Cr}$, and $\mathrm{Cu}$ (Figure 6) are at similarly low level. As can be seen from literature data and the calculated Clarke values for coal and its ashes [47], the W [41], Zr [48,49], Hf [50,51], Nb [37,52], and Cr [53,54] concentrations in coal may be sufficiently high to justify their recovery. When it comes to $\mathrm{Bi}, \mathrm{Cu}$, and $\mathrm{Y}$ concentrations in the ash from the combustion of sample 1, they were shown to be above their average Clarke values but at the same time well below the designated Clarke value for coal ash.

Molybdenum (Mo) is also used in the aerospace and defense industries, and its average abundance in the Earth's crust is 1 ppm. The molybdenum content in ash is higher than its average abundance in the Earth's crust. In bituminous coal (samples 1 and 2) and lignite (sample 3) ashes, the concentrations are lower than the Clarke value (Figure 5). As demonstrated by Dai and Finkelman [37], Mo can be recovered from some ashes and coal deposits, provided that it is highly concentrated.

According to [37], antimony ( $\mathbf{S b}$ ) is promising for utilization due to the fact that highlyelevated concentration elements in coal and coal ash have been found and are comparable to, or even higher than, those found in conventional ores; however, the extraction technologies have not been evaluated. Antimony is very important as it is used in the doping of 
semiconductors-for example, InSb (indium antimonide) forms n-type semiconductors. The abundance of antimony in the Earth's crust 0.2 ppm, but the Clarke value for coal and ashes is higher. According to some studies, it can be recovered from ash coal combustion in power plants $[55,56]$. In the tested samples, the highest $\mathrm{Sb}$ concentrations, up to $10 \mathrm{ppm}$, were measured in fly ash (Figure 5, Table 2).

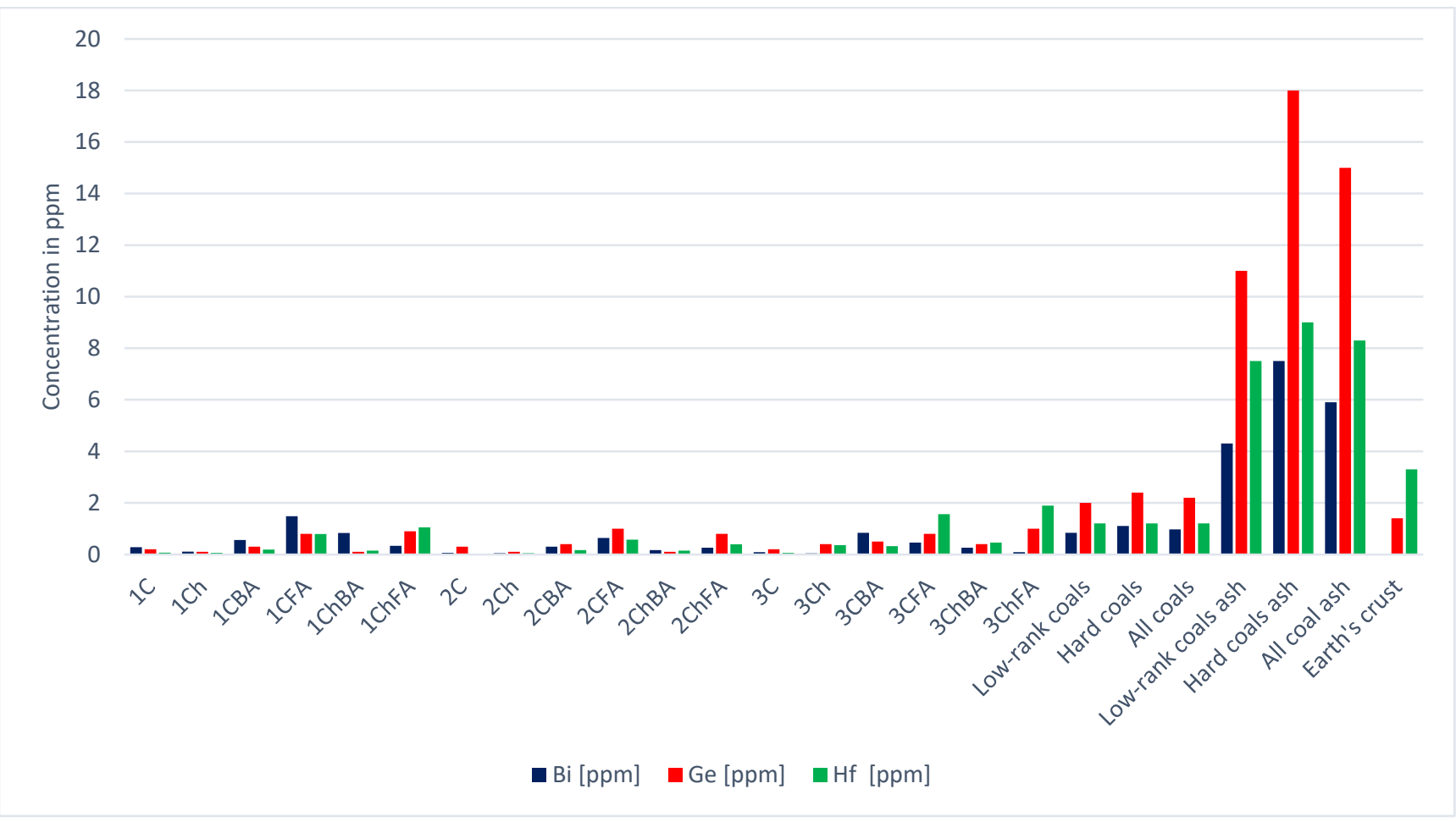

Figure 3. The Bi, Ge, and Hf content of coal, char, ashes and their Clarke values [21].

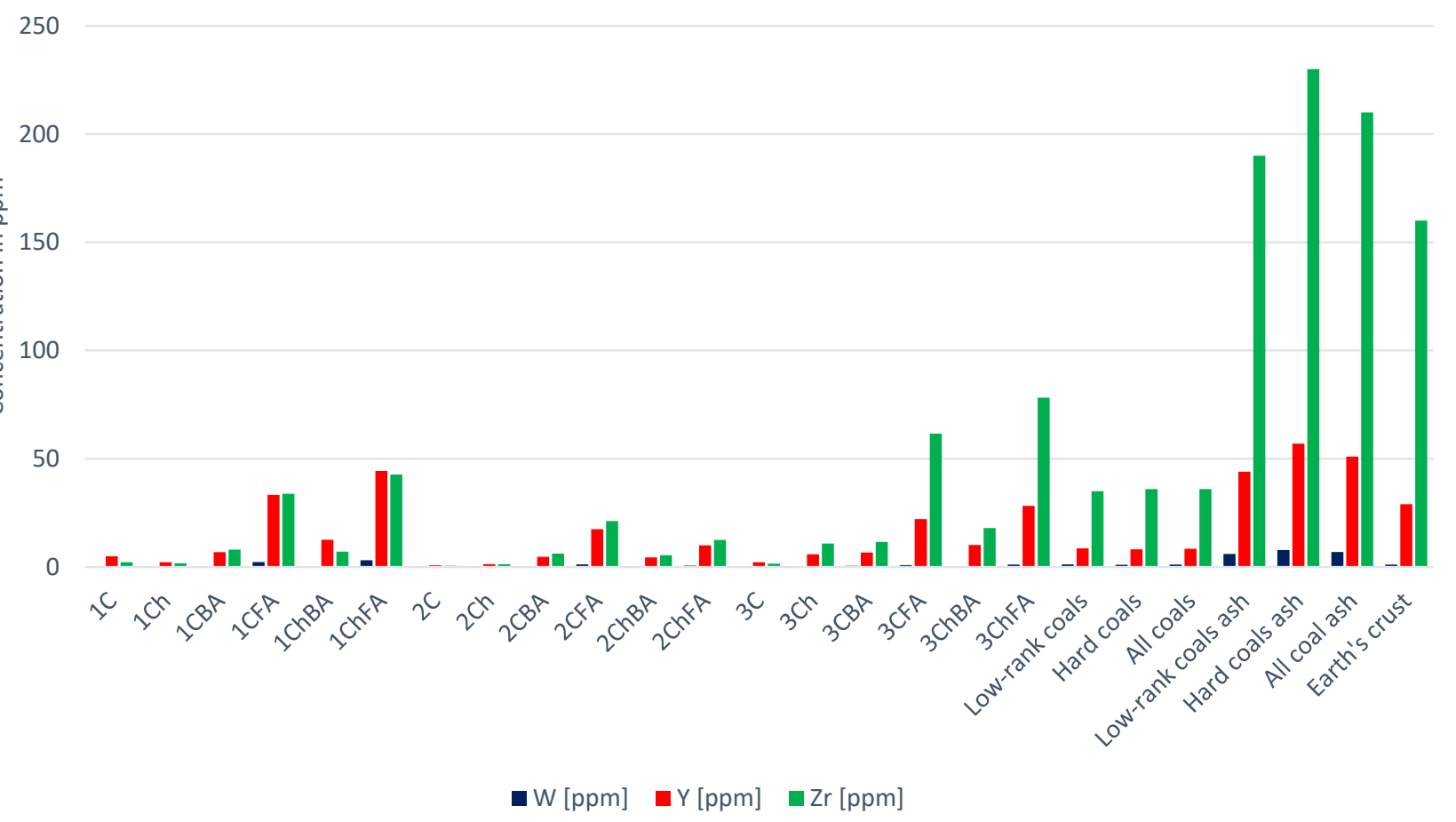

Figure 4. The W, Y, and Zr content of coal, char, ashes and their Clarke values [21]. 
25

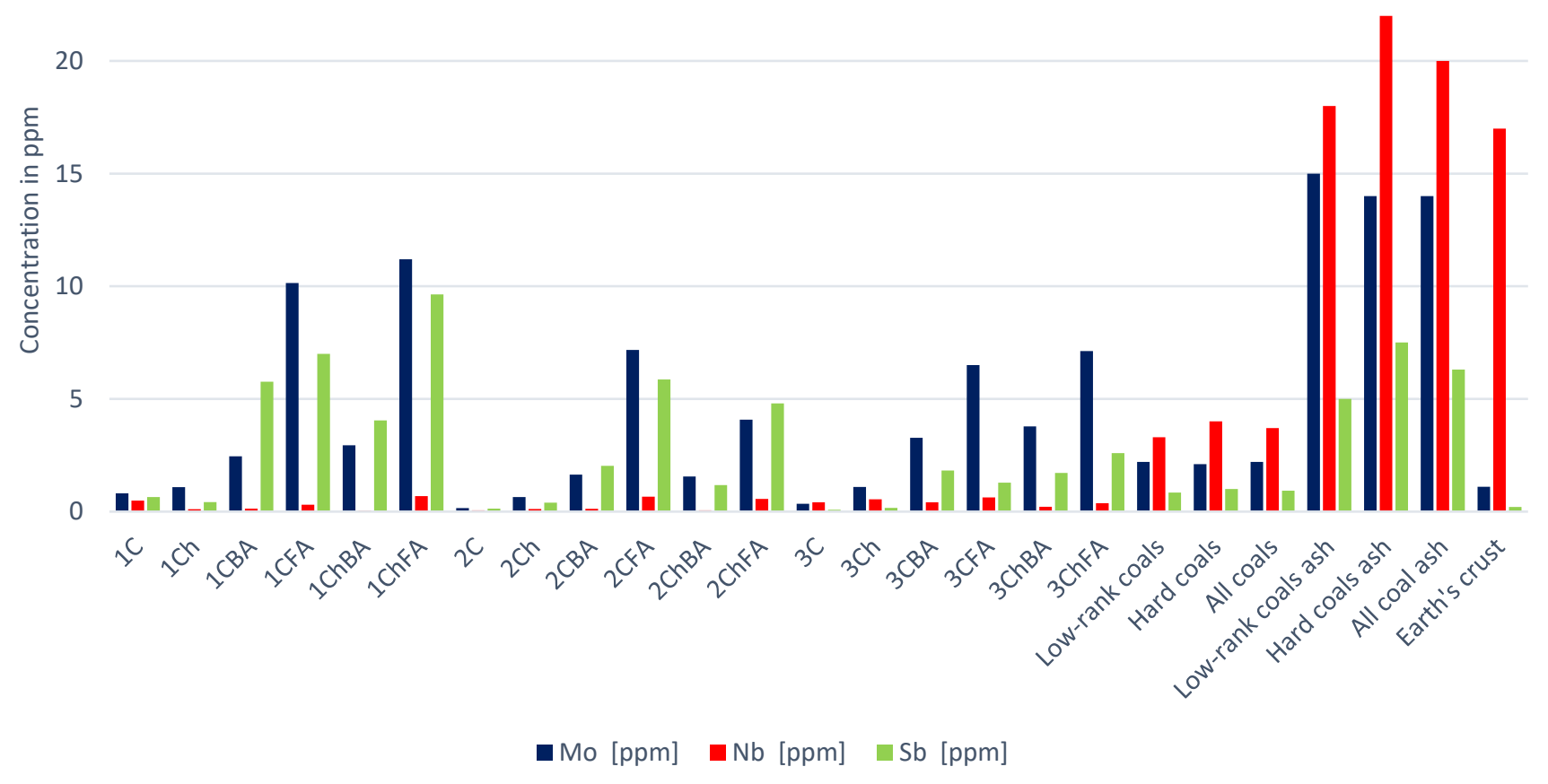

Figure 5. The $\mathrm{Mo}, \mathrm{Nb}$, and $\mathrm{Sb}$ content of coal, char, ashes and their Clarke values [21].

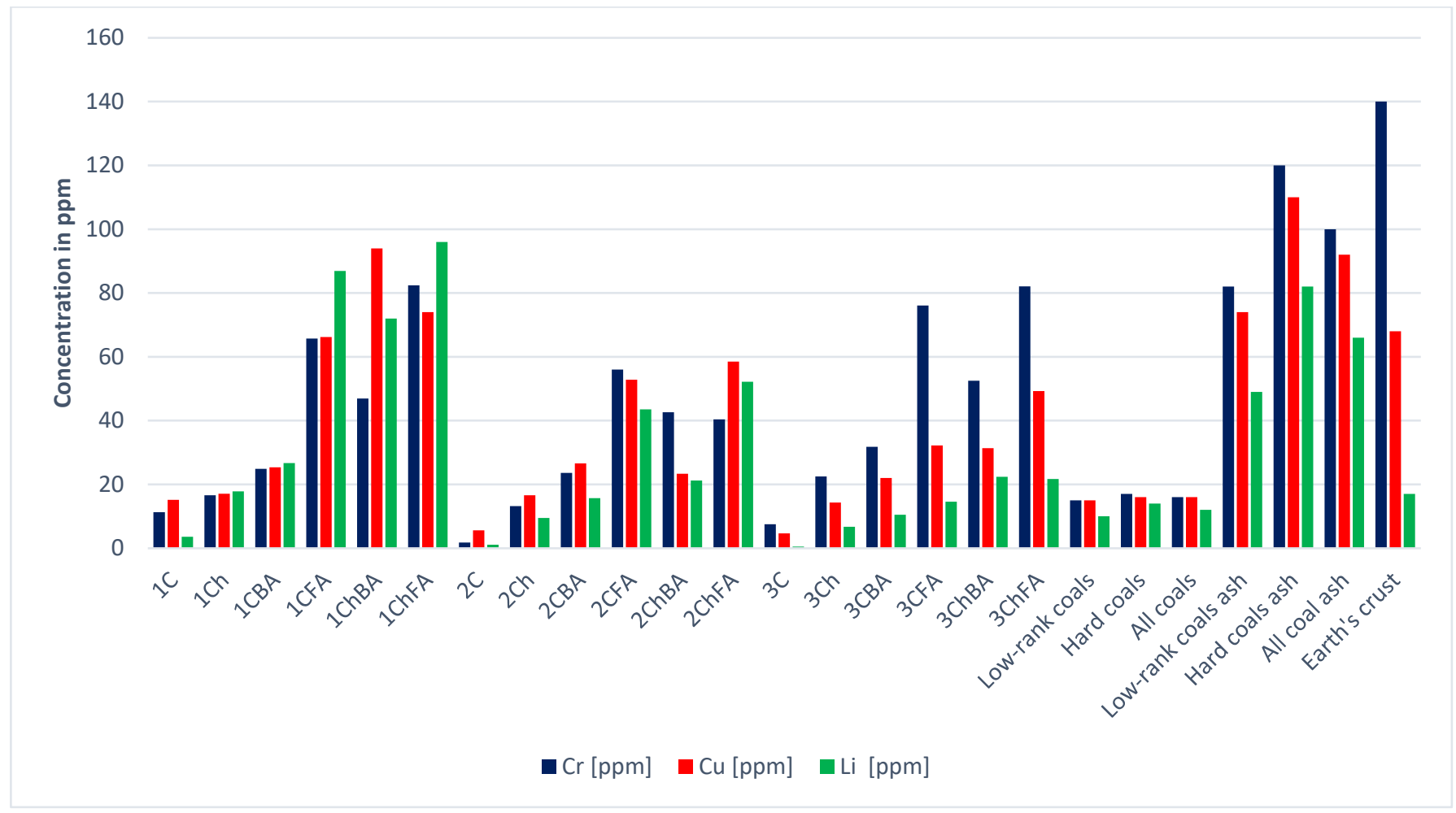

Figure 6. The $\mathrm{Cr}, \mathrm{Cu}$, and Li content of coal, char, ashes and their Clarke values [21].

At the end of the 20th century, lithium ( $\mathrm{Li}$ ) became one of the most important elements, which is used in lithium-ion batteries due to its low standard potential. There has also been a significant increase in interest in obtaining lithium from various sources due to the increasing demand for batteries. Therefore, research into the possibility of extracting it from 
coal and its ashes is being carried out all over the world. Based on several publications by Chinese scientists, it is possible to recover lithium from coal and ashes [57-60]. The lithium content of the analyzed samples is very diverse. In samples 1 and 2 (bituminous coal), the lithium content of fly ash exceeds its Clarke value. In addition, lithium concentrations in the ash from sample 1 and 2 are higher than in the Earth's crust. However, these concentrations are not high enough to make their recovery economically viable using current technology.

The beryllium (Be), cesium (Cs), and selenium ( $\mathrm{Se}$ ) concentrations and the possibility of their recovery from the tested ashes deserve special attention. In the tested samples, high Be and Cs concentrations were found in the fly ash sample no. 1, while elevated Se concentrations were recorded for the fly ash sample no. 3 . Their concentrations are higher than their Clarke values in coal ashes and in the Earth's crust (Figure 7).

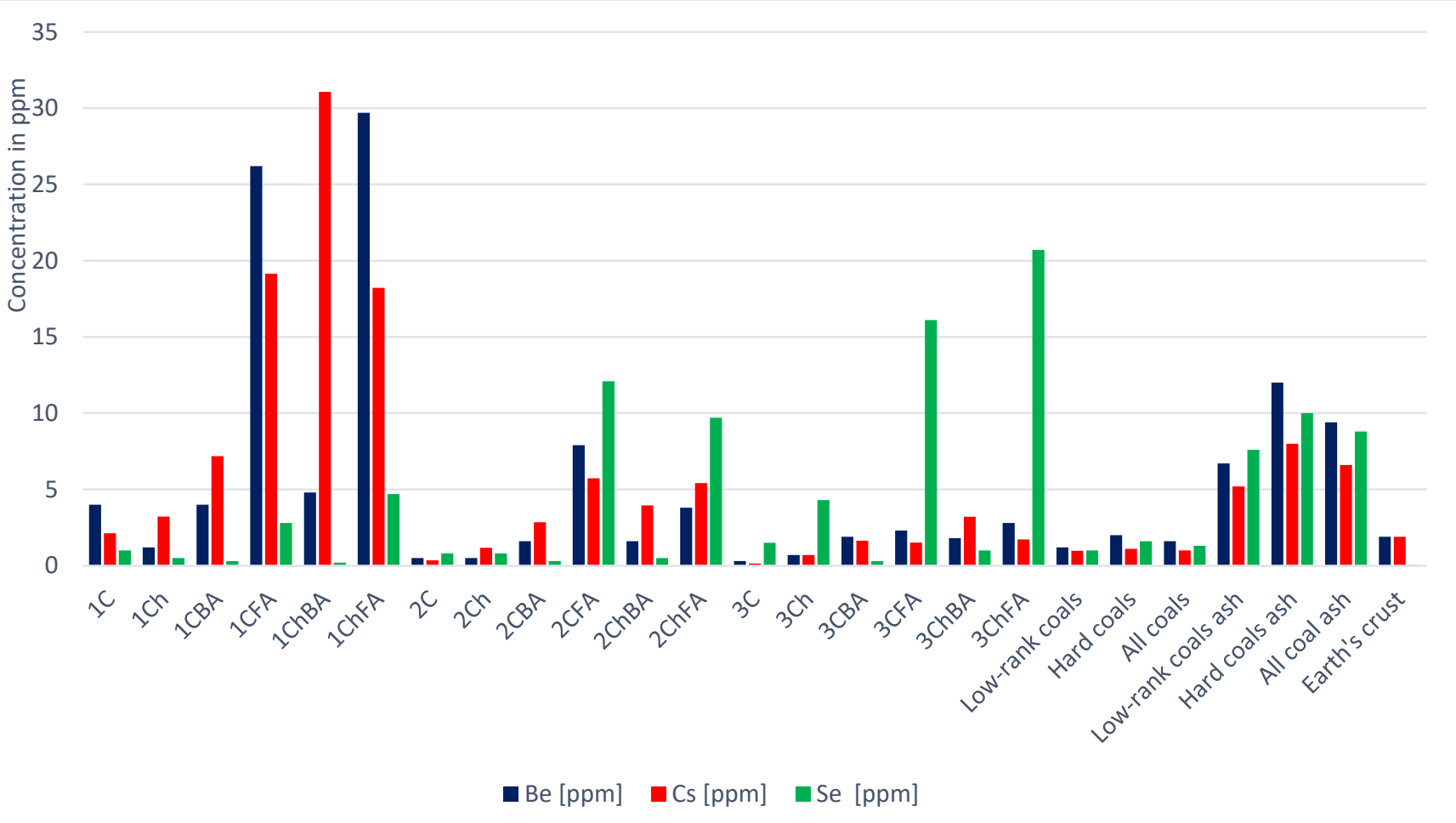

Figure 7. The Be, Cs, and Se content of coal, char, and ashes and their Clarke values [21].

Beryllium has a very wide range of applications, mainly in nuclear and radiation technology and in the production of rocket fuel. Its average abundance in the Earth's crust is $1.9 \mathrm{ppm}$. The maximum Be concentration (30 ppm) was measured in a fly ash sample from the combustion of coal char 1 (Figure 7). Extensive research is currently being conducted on the recovery of this element from coal waste [37,61]. In addition, cesium can be recovered from coal and its ashes and is highly promising for utilization [37]. Cesium is mainly used in photoelectric cells due to its strong photoelectric effect. This metal is also used in infrared radiation sensors. In organic synthesis, it is used as a catalyst in the hydration process. The isotope ${ }^{137} \mathrm{Cs}$ (a source of gamma radiation) is used in medicine to fight cancer. It should be noted here that cesium is also dangerous for humans and the environment due to its radiation [62]. The highest concentrations of Ce in the tested samples were determined in fly ash and bottom ash from the combustion of char (31 ppm) (Figure 7). Cesium is taken up by all plants and it enters them very easily, using the same channels as potassium. Therefore, higher concentrations of Cs in coal, which is formed from plant debris, are expected.

Selenium is used in photovoltaic cells and as a semiconductor. Currently, Se is recovered [63-65] from coal ashes. The maximum Se content (21 ppm) was measured in fly ash 
from the combustion of lignite char. Selenium is a very coalphile element: it has strong affinity to coal matter-both organic and inorganic, but is certainly authigenic [66]. Given the fact that the tested lignite is sulphated, its concentrations should be related to pyrite compounds [66].

Fly ash from the combustion of sample no. 1 also had higher vanadium $(V)$ and zinc (Zn) concentrations than the Clarke in coal ash (Figure 8). Vanadium is a heavy metal that is widely used in industrial applications. It is mainly used in the production of nonferrous alloys, highly resistant carbon steels, and in the chemical, glass, ceramic, dyeing, and photographic industries. Vanadium can be associated with and obtained from coal deposits [11]. In China, about $87 \%$ of vanadium is obtained from stone coal $[25,67,68]$. At the same time, work is also being carried out on the recovery of vanadium from gasification waste [69-71]. However, it must be stated that the concentrations present in the samples are not high and their recovery is not cost-effective.

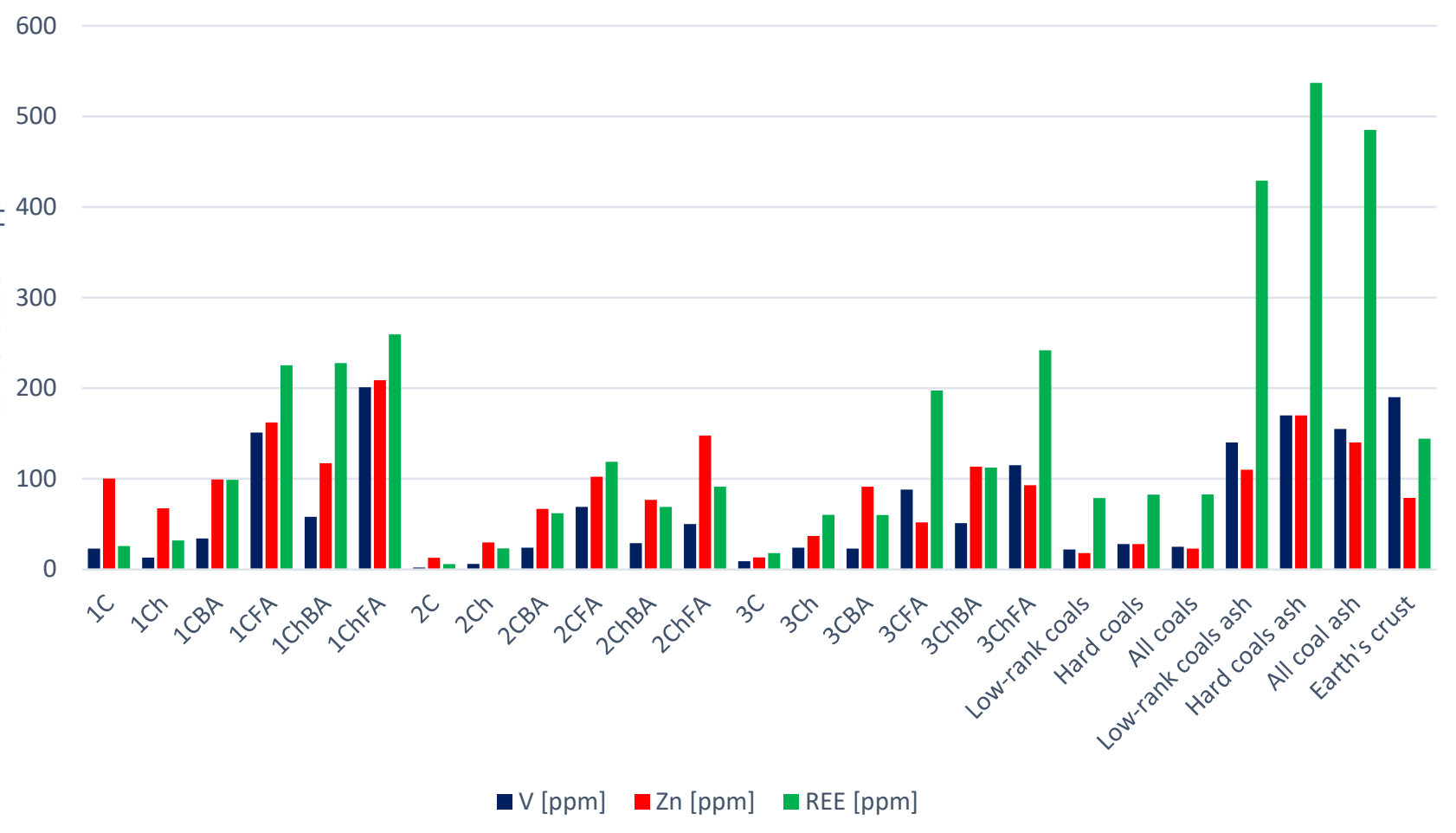

Figure 8. The V, Zn, and REE content of char ashes and their Clarke values [21].

The zinc (Figure 8) and rubidium (Rb) (Figure 9) concentrations in some of the ashes are higher than the Clarke in the Earth's crust; however, the Zn concentration exceeded the Clarke for ash in only one fly ash sample (1ChFA). Therefore, one should not hope to recover $\mathrm{Zn}$ and $\mathrm{Rb}$ from coal waste. A similar conclusion was also reached by Dai and Finkelman [37].

With the development of modern technologies, the demand for REE (rare-earth elements), 17 chemical elements, which include two elements from the scandium group (scandium and yttrium) and all lanthanides, has also increased. Currently, intensive work is being carried out on the recovery of REE from coal deposits and coal ash [72-75]. In some coal deposits, mainly in China [76-80], REE concentrations are higher than their Clarke values. However, much higher concentrations are observed in ashes [25,81-83]. Similar results were also obtained during the analysis of waste. REEs were found to concentrate mainly in fly ash, but the measured volumes in some samples were only higher than the REE abundance in the Earth's crust and lower than the Clarke in the ash (Figure 8). For this reason, the tested materials cannot be used as raw materials for REE production. 


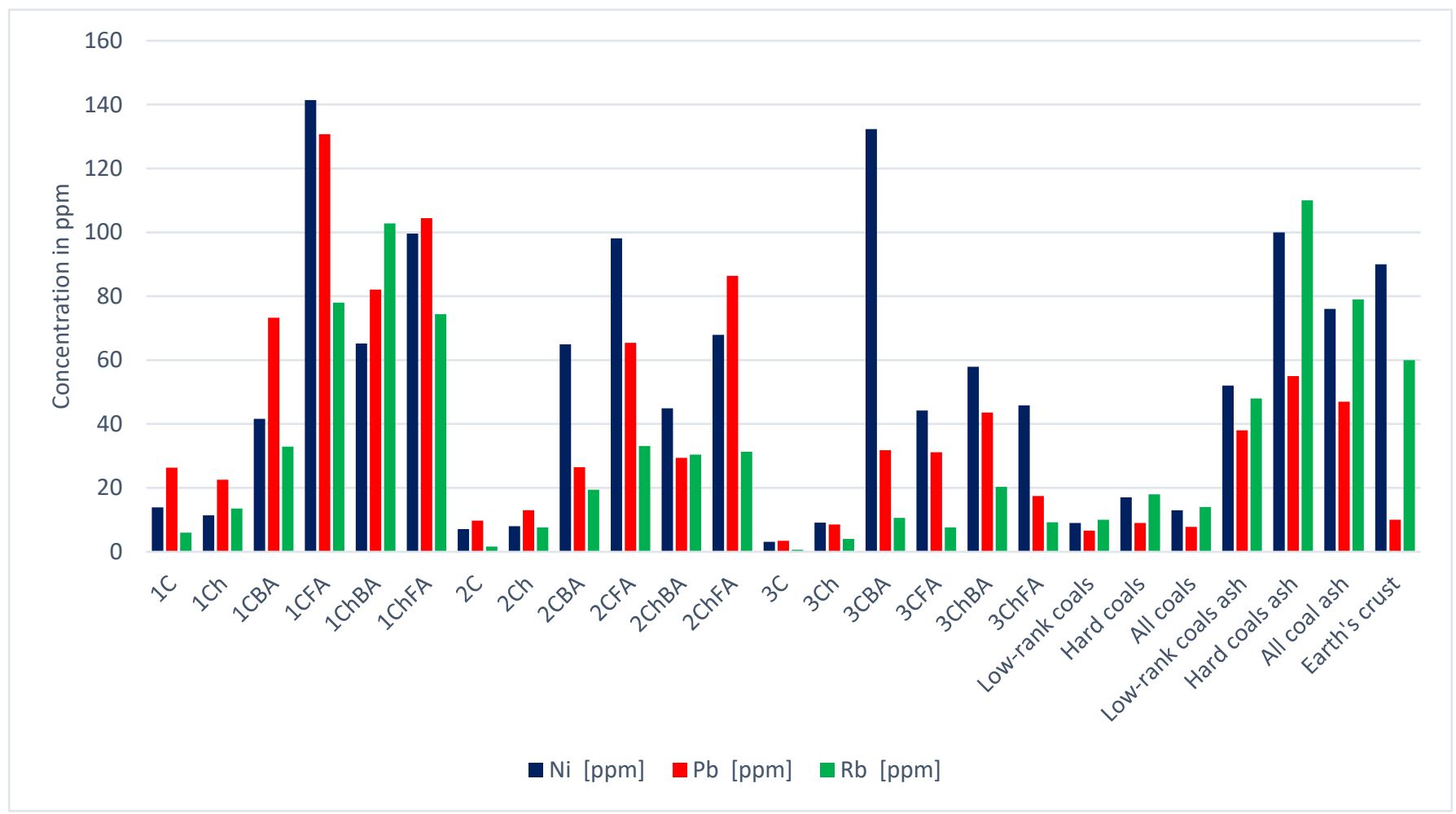

Figure 9. The $\mathrm{Ni}, \mathrm{Pb}$, and $\mathrm{Rb}$ content of coal, char, and ashes and their Clarke values [21].

Among other metals, nickel (Ni) stands out for its versatility of applications. It is valued for its heat resistance, ferromagnetic properties, and corrosion resistance. It is used as an important additive to ferrous and non-ferrous alloys. Nickel and nickel alloys play an extremely important role in today's industry due to their performance under adverse conditions. About 70\% Nickel is used as an additive in alloy steels, mainly stainless steel. Nickel alloys consume about $13 \%$ of the nickel production; a further $10 \%$ is used in plating. In its pure form, the metal is used in electronics and electrical engineering, the food industry, in research equipment and in the aviation and aerospace industries. In the tested samples, nickel is concentrated mainly in ashes (Figure 9), similar to what was shown by [84,85]. There are currently ongoing studies on recovering Ni from the ashes. However, to date, these studies have not produced satisfactory results [86,87].

In all tested fly ashes, the lead $(\mathbf{P b})$ concentration was found to be higher than the Clarke value in the Earth's crust (Figure 9). The highest Pb concentration (131 ppm) was found in the fly ash from coal combustion (sample 1). Lead concentrations in samples 1 and 2 are also higher than the Clarke value in coal ash. Lead has a wide range of applications in metallurgy, construction, and the military industry. It is used to create structural elements-sheets, plates, and claddings. It is commonly added to brass and bronze. It is used in noise barriers and radiation shielding. It is used as a coolant and as a component of lead-acid batteries. However, it is also a toxic element. The lead content in coal and ash was usually tested in terms of its environmental impact $[53,88]$. It is not economically viable to recover lead from coal waste due to its low concentrations and the fact it is obtained from other sources.

Based on the obtained results, it can be stated that the content of selected CRMs is highly dependent on the mineral matter content of the starting material. The coal affinity indexes [89] confirm that the fly ashes from combustion of raw coal and chars contain the highest amounts of elements that can be recovered. This is related to the volatility of the elements, i.e., their release with the volatile products of the process. In the examined samples, this relationship is particularly evident in the case of selenium, high levels of which are observed in fly ash samples. 


\section{Conclusions}

The main objective of this study was to examine the possibility of recovery of selected critical raw materials from waste generated during coal gasification. The foremost findings of this work can be summarized as follows:

As shown by the analysis of the literature and data from various companies, it is possible to recover critical raw materials from coal and its ashes. Already at this point Ge, Se, and $\mathrm{V}$ are recovered.

Several gallium facilities are in the demonstration stage. However, for the most part, these projects are carried out in China, from where a large proportion of the critical elements are sourced.

It has been found that the tested coal does not contain the selected critical raw materials as in the case of coal from Inner Mongolia deposits (China).

The most prospective material for obtaining CRMs is ash, mainly fly ash. With the use of appropriate enrichment technology and metallurgical methods, it would be possible to recover $\mathrm{Be}, \mathrm{Cs}$, or $\mathrm{Sb}$ from bituminous coal ashes.

Regarding the possibility of recovering Se from lignite, additional studies need to be carried out.

Taking into account the adopted cut-off grade levels for individual critical raw materials, it is not economically viable to recover $\mathrm{Pb}$ and $\mathrm{Ni}$ from the ashes despite the fact that they show enrichment factors in relation to the content in the Earth's crust.

In order to truly assess the potential for recovery, in addition to chemical testing, petrographic analysis, a micro-area analysis is also required to determine the forms of occurrence of the discussed elements

With regard to the adopted cut-off grades and the trend in the exploration of CRMs in Polish coals and gasification waste, it should be stated that the concentrations of critical raw materials are too low for their recovery to be economically feasible.

Analysis of the occurrence and consequently the potential recovery of raw materials from gasification wastes will allow a comprehensive use of the extracted raw material for power generation and as a source of CRMs.

The analyses conducted allow us to extend the CRMs resource base in the future.

The search for CRMs in gasification waste can help to move toward a circular economy.

Supplementary Materials: The following are available online at https://www.mdpi.com/article/ $10.3390 /$ en14238071/s1.

Funding: This research was funded by the Ministry of Science and Higher Education (subsidy no. 16.16.140.315).

Institutional Review Board Statement: Not applicable.

Informed Consent Statement: Not applicable.

Data Availability Statement: Not applicable.

Conflicts of Interest: The authors declare no conflict of interest.

\section{References}

1. Higman, C.; van der Burgt, M. Gasification; Gulf Professional Pub./Elsevier Science: Amsterdam, The Netherlands, 2008; ISBN 9780080560908.

2. Bielowicz, B.; Kasiński, J.R.J.R. The possibility of underground gasification of lignite from Polish deposits. Int. J. Coal Geol. 2014, 131, 304-318. [CrossRef]

3. Produkcja Energii Elektrycznej w Polsce I Rynek Elektryczny. Available online: https:/ /www.rynekelektryczny.pl/produkcjaenergii-elektrycznej-w-polsce/ (accessed on 27 May 2021).

4. Ministry of Energy. Polish Energy Policy until 2040 (Polityka Energetyczna Polski do 2040) PEP2040. 2018. Available online: https://www.gov.pl/web/klimat/polityka-energetyczna-polski (accessed on 4 October 2021).

5. Radwanek-Bąk, B. Zasoby kopalin Polski w aspekcie oceny surowców krytycznych Unii Europejskiej. Gospod. Surowcami Miner.-Miner. Resour. Manag. 2011, 27, 5-19. 
6. Federal Register: Final List of Critical Minerals 2018. Available online: https:/ /www.federalregister.gov/documents/2018/05/ 18/2018-10667 / final-list-of-critical-minerals-2018 (accessed on 4 October 2021).

7. 5-Year National Plan on Mineral Resources Approved. Available online: http://www.scio.gov.cn/32618/Document/1518844/15 18844.htm (accessed on 4 October 2021).

8. Australia's Critical Minerals Strategy I Department of Industry, Science, Energy and Resources. Available online: https://www. industry.gov.au/data-and-publications/australias-critical-minerals-strategy (accessed on 4 October 2021).

9. Tang, Y.; Guo, X.; Pan, X.; Finkelman, R.B.; Wang, Y.; Huan, B.; Wang, S. Changes and distribution of modes of occurrence of seventeen potentially-hazardous trace elements during entrained flow gasification of coals from Ningdong, China. Minerals 2018, 8, 202. [CrossRef]

10. Niu, M.; Fu, Y.; Liu, S. Distribution and leachability of hazardous trace elements in Lurgi gasification ash from a Coal-to-SNG plant. J. Energy Inst. 2021, 98, 223-233. [CrossRef]

11. Bielowicz, B. Ash characteristics and selected critical elements (Ga, Sc, V) in coal and ash in polish deposits. Resources 2020, 9, 115. [CrossRef]

12. Dai, S.; Seredin, V.V.; Ward, C.R.; Jiang, J.; Hower, J.C.; Song, X.; Jiang, Y.; Wang, X.; Gornostaeva, T.; Li, X.; et al. Composition and modes of occurrence of minerals and elements in coal combustion products derived from high-Ge coals. Int. J. Coal Geol. 2014, 121, 79-97. [CrossRef]

13. Alonso, E.; Sherman, A.M.; Wallington, T.J.; Everson, M.P.; Field, F.R.; Roth, R.; Kirchain, R.E. Evaluating rare earth element availability: A case with revolutionary demand from clean technologies. Environ. Sci. Technol. 2012, 46, 3406-3414. [CrossRef]

14. Blissett, R.S.; Rowson, N.A. A review of the multi-component utilisation of coal fly ash. Fuel 2012, 97, 1-23. [CrossRef]

15. Blissett, R.S.S.; Smalley, N.; Rowson, N.A.A. An investigation into six coal fly ashes from the United Kingdom and Poland to evaluate rare earth element content. Fuel 2014, 119, 236-239. [CrossRef]

16. Querol, X.; JoséLuis, F.-T.; Angel, L.-T. Trace elements in coal and their behavior during combustion in a large power station. Fuel 1995, 74, 331-343. [CrossRef]

17. Franus, W.; Wiatros-Motyka, M.M.; Wdowin, M. Coal fly ash as a resource for rare earth elements. Environ. Sci. Pollut. Res. 2015, 22, 9464-9474. [CrossRef]

18. Wang, Z.; Dai, S.; Zou, J.; French, D.; Graham, I.T. Rare earth elements and yttrium in coal ash from the Luzhou power plant in Sichuan, Southwest China: Concentration, characterization and optimized extraction. Int. J. Coal Geol. 2019, 203, 1-14. [CrossRef]

19. Fu, B.; Hower, J.C.; Zhang, W.; Luo, G.; Hu, H.; Yao, H. A review of rare earth elements and yttrium in coal ash: Content, modes of occurrences, combustion behavior, and extraction methods. Prog. Energy Combust. Sci. 2022, 88, 100954. [CrossRef]

20. Guo, X.; Tang, Y.; Wang, Y.; Eble, C.F.; Finkelman, R.B.; Huan, B.; Pan, X. Potential utilization of coal gasification residues from entrained-flow gasification plants based on rare earth geochemical characteristics. J. Clean. Prod. 2021, 280, 124329. [CrossRef]

21. Ketris, M.P.; Yudovich, Y.E. Estimations of Clarkes for Carbonaceous biolithes: World averages for trace element contents in black shales and coals. Int. J. Coal Geol. 2009, 78, 135-148. [CrossRef]

22. Seredin, V.V. Metalliferous coals: Formation conditions and outlooks for development. Coal Resour. Russ. 2004, 6, $452-519$.

23. Seredin, V.V.; Finkelman, R.B. Metalliferous Coals: A Review of the Main Genetic and Geochemical Types; Elsevier: Amsterdam, The Netherlands, 2008; Volume 76, pp. 253-289.

24. Dai, S.; Wang, X.; Seredin, V.V.; Hower, J.C.; Ward, C.R.; O’Keefe, J.M.K.; Huang, W.; Li, T.; Li, X.; Liu, H.; et al. Petrology, mineralogy, and geochemistry of the Ge-rich coal from the Wulantuga Ge ore deposit, Inner Mongolia, China: New data and genetic implications. Int. J. Coal Geol. 2012, 30-31, 72-99. [CrossRef]

25. Dai, S.; Ren, D.; Chou, C.L.; Finkelman, R.B.; Seredin, V.V.; Zhou, Y. Geochemistry of trace elements in Chinese coals: A review of abundances, genetic types, impacts on human health, and industrial utilization. Int. J. Coal Geol. 2012, 94, 3-21. [CrossRef]

26. ISO-ISO 589:2008-Hard Coal—Determination of Total Moisture. Available online: https://www.iso.org/standard/45370.html (accessed on 28 October 2021).

27. ISO 1171. Solid Mineral Fuels-Determination of Ash. 2010. Available online: https://www.iso.org/standard/55944.html (accessed on 28 October 2021).

28. ISO 562. Hard Coal and Coke-Determination of Volatile Matter. 2010. Available online: https://www.iso.org/standard/55943. html (accessed on 28 October 2021).

29. ISO 1928. Coal and Coke-Determination of Gross Calorific Value. 2020. Available online: https://www.iso.org/standard/75883. html (accessed on 28 October 2021).

30. ISO-ISO 29541:2010—Solid Mineral Fuels—Determination of Total Carbon, Hydrogen and Nitrogen Content-Instrumental Method. Available online: https:/ / www.iso.org/standard/45546.html (accessed on 28 October 2021).

31. ISO-ISO 19579:2006—Solid Mineral Fuels—Determination of Sulfur by IR Spectrometry. Available online: https://www.iso. org/standard/39113.html (accessed on 28 October 2021).

32. ISO 7404-5. Methods for the Petrographic Analysis of Coals-Part 5: Method of Determining Microscopically the Reflectance of Vitrinite. 2009. Available online: https:/ / www.iso.org/standard/42832.html (accessed on 28 October 2021).

33. ISO 7404-3. Methods for the Petrographic Analysis of Coals-Part 3: Method of Determining Maceral Group Composition. 2009. Available online: https://www.iso.org/standard/42831.html (accessed on 28 October 2021).

34. Chmielniak, T.; Ściążko, M.; Sobolewski, A.; Tomaszewicz, G.; Popowicz, J. Coal gasification with $\mathrm{CO}_{2}$ as Gasification agent-As a method for improving emission factors and process efficiency. Polityka Energetyczna 2014, 15, 125-138. 
35. Chmielniak, T.; Sobolewski, A.; Tomaszewicz, G. $\mathrm{CO}_{2}$-Enhanced coal gasification. Experience of the Institute for Chemical Processing of Coal Zgazowanie węgla przy wykorzystaniu $\mathrm{CO}_{2}$ jako czynnika zgazowującego. Doświadczenia IChPW. Przemyst Chemiczny 2015, 1, 16-22. [CrossRef]

36. Błaszczuk, A.; Nowak, W.; Jagodzik, S. Bed-to-wall heat transfer in a supercritical circulating fluidised bed boiler. Chem. Process. Eng.-Inz. Chem. Proces. 2014, 35, 191-204. [CrossRef]

37. Dai, S.; Finkelman, R.B. Coal as a Promising Source of Critical Elements: Progress and Future Prospects; Elsevier B.V.: Amsterdam, The Netherlands, 2018; Volume 186, pp. 155-164.

38. Eskenazy, G.M. On the geochemistry of indium in coal-forming process. Geochim. Cosmochim. Acta 1980, 44, 1023-1027. [CrossRef]

39. Wei, Q.; Cui, C.; Dai, S. Organic-association of Ge in the coal-hosted ore deposits: An experimental and theoretical approach. Ore Geol. Rev. 2020, 117, 103291. [CrossRef]

40. Dai, S.; Liu, J.; Ward, C.R.; Hower, J.C.; Xie, P.; Jiang, Y.; Hood, M.M.; O’Keefe, J.M.K.; Song, H. Petrological, geochemical, and mineralogical compositions of the low-Ge coals from the Shengli Coalfield, China: A comparative study with Ge-rich coals and a formation model for coal-hosted Ge ore deposit. Ore Geol. Rev. 2015, 71, 318-349. [CrossRef]

41. Etschmann, B.; Liu, W.; Li, K.; Dai, S.; Reith, F.; Falconer, D.; Kerr, G.; Paterson, D.; Howard, D.; Kappen, P.; et al. Enrichment of germanium and associated arsenic and tungsten in coal and roll-front uranium deposits. Chem. Geol. 2017, 29-49. [CrossRef]

42. Font, O.; Querol, X.; López-Soler, A.; Chimenos, J.M.; Fernández, A.I.; Burgos, S.; García Peña, F. Ge extraction from gasification fly ash. Fuel 2005, 84, 1384-1392. [CrossRef]

43. Arroyo, F.; Font, O.; Chimenos, J.M.; Fernández-Pereira, C.; Querol, X.; Coca, P. IGCC fly ash valorisation. Optimisation of Ge and Ga recovery for an industrial application. Fuel Process. Technol. 2014, 124, 222-227. [CrossRef]

44. Zhuang, X.; Querol, X.; Alastuey, A.; Juan, R.; Plana, F.; Lopez-Soler, A.; Du, G.; Martynov, V.V. Geochemistry and mineralogy of the Cretaceous Wulantuga high-germanium coal deposit in Shengli coal field, Inner Mongolia, Northeastern China. Int. J. Coal Geol. 2006, 66, 119-136. [CrossRef]

45. Hernández-Expósito, A.; Chimenos, J.M.; Fernández, A.I.; Font, O.; Querol, X.; Coca, P.; García Peña, F. Ion flotation of germanium from fly ash aqueous leachates. Chem. Eng. J. 2006, 118, 69-75. [CrossRef]

46. Arroyo, F.; Fernández-Pereira, C.; Olivares, J.; Coca, P. Hydrometallurgical recovery of germanium from coal gasification fly ash: Pilot plant scale evaluation. Ind. Eng. Chem. Res. 2009, 48, 3573-3579. [CrossRef]

47. Yudovich, Y.E.; Ketris, M.P. Arsenic in coal: A review. Int. J. Coal Geol. 2005, 61, 141-196. [CrossRef]

48. Zhao, L.; Dai, S.; Nechaev, V.P.; Nechaeva, E.V.; Graham, I.T.; French, D.; Sun, J. Enrichment of critical elements (Nb-Ta-Zr-Hf-REE) within coal and host rocks from the Datanhao mine, Daqingshan Coalfield, northern China. Ore Geol. Rev. 2019, 111, 102951. [CrossRef]

49. Hower, J.C.J.C.; Ruppert, L.F.L.F.; Eble, C.F.C.F. Lanthanide, yttrium, and zirconium anomalies in the Fire Clay coal bed, Eastern Kentucky. Int. J. Coal Geol. 1999, 39, 141-153. [CrossRef]

50. Dai, S.; Liu, J.; Ward, C.R.; Hower, J.C.; French, D.; Jia, S.; Hood, M.M.; Garrison, T.M. Mineralogical and geochemical compositions of Late Permian coals and host rocks from the Guxu Coalfield, Sichuan Province, China, with emphasis on enrichment of rare metals. Int. J. Coal Geol. 2016, 166, 71-95. [CrossRef]

51. Eskenazy, G.M. Zirconium and hafnium in Bulgarian coals. Fuel 1987, 66, 1652-1657. [CrossRef]

52. Dai, S.; Yan, X.; Ward, C.R.; Hower, J.C.; Zhao, L.L.; Wang, X.; Zhao, L.L.; Ren, D.; Finkelman, R.B. Valuable elements in Chinese coals: A review. Int. Geol. Rev. 2018, 60, 590-620. [CrossRef]

53. Cui, W.; Meng, Q.; Feng, Q.; Zhou, L.; Cui, Y.; Li, W. Occurrence and release of cadmium, chromium, and lead from stone coal combustion. Int. J. Coal Sci. Technol. 2019, 6, 586-594. [CrossRef]

54. Travar, I.; Kihl, A.; Kumpiene, J. Utilization of air pollution control residues for the stabilization/solidification of trace element contaminated soil. Environ. Sci. Pollut. Res. 2015, 22, 19101-19111. [CrossRef]

55. Eskenazy, G.M. Geochemistry of arsenic and antimony in Bulgarian coals. Chem. Geol. 1995, 119, 239-254. [CrossRef]

56. Narukawa, T.; Takatsu, A.; Chiba, K.; Riley, K.W.; French, D.H. Investigation on chemical species of arsenic, selenium and antimony in fly ash from coal fuel thermal power stations. J. Environ. Monit. JEM 2005, 7, 1342-1348. [CrossRef] [PubMed]

57. Sun, Y.; Zhao, C.; Li, Y.; Wang, J.; Liu, S. Li distribution and mode of occurrences in Li-bearing coal seam \# 6 from the Guanbanwusu Mine, Inner Mongolia, northern China. Energy Explor. Exploit. 2012, 30, 109-130. [CrossRef]

58. Sun, Y.; Yang, J.; Zhao, C. Minimum mining grade of associated Li deposits in coal seams. Energy Explor. Exploit. 2012, 30, 167-170. [CrossRef]

59. Hu, P.; Hou, X.; Zhang, J.; Li, S.; Wu, H.; Damø, A.J.; Li, H.; Wu, Q.; Xi, X. Distribution and occurrence of lithium in high-aluminacoal fly ash. Int. J. Coal Geol. 2018, 189, 27-34. [CrossRef]

60. Qin, S.; Zhao, C.; Li, Y.; Zhang, Y. Review of Coal as a Promising Source of Lithium; Inderscience Enterprises Ltd.: Geneva, Switzerland, 2015; Volume 9, pp. 215-229.

61. Norris, P.; Chen, C.W.; Pan, W.P. A technique for sequential leaching of coal and fly ash resulting in good recovery of trace elements. Anal. Chim. Acta 2010, 663, 39-42. [CrossRef]

62. Occurrence of Rubidium and Cesium in Iqe Coal, Qinghai-Tibet Plateau: Evidence from Sequential Chemical Extraction Experiment-Cunliang Zhao, Bangjun Liu, Jialiang Ma, Shiming Liu, Maksim G Blokhin. 2017. Available online: https: //journals.sagepub.com/doi/full/10.1177/0144598717690088 (accessed on 18 October 2021). 
63. Su, T.; Wang, J. Modeling batch leaching behavior of arsenic and selenium from bituminous coal fly ashes. Chemosphere 2011, 85, 1368-1374. [CrossRef]

64. Li, X.; Dai, S.; Zhang, W.; Li, T.; Zheng, X.; Chen, W. Determination of As and Se in coal and coal combustion products using closed vessel microwave digestion and collision/reaction cell technology (CCT) of inductively coupled plasma mass spectrometry (ICP-MS). Int. J. Coal Geol. 2014, 124, 1-4. [CrossRef]

65. Gerson, A.R.; Fan, R.; Qian, G.; Schumann, R.C.; Olin, P.; Howard, D.L.; Smart, R.S.C. Examination of multiple sources of selenium release from coal wastes and strategies for remediation. J. Hazard. Mater. 2022, 422, 126924. [CrossRef] [PubMed]

66. Yudovich, Y.E.; Ketris, M.P. Selenium in coal: A review. Int. J. Coal Geol. 2006, 67, 112-126. [CrossRef]

67. Deng, Z.G.; Wei, C.; Fan, G.; Li, M.T.; Li, C.X.; Li, X. Bin Extracting vanadium from stone-coal by oxygen pressure acid leaching and solvent extraction. Trans. Nonferrous Met. Soc. China 2010, 20, S1003-S6326. [CrossRef]

68. Zhang, Y.M.; Bao, S.X.; Liu, T.; Chen, T.J.; Huang, J. The technology of extracting vanadium from stone coal in China: History, current status and future prospects. Hydrometallurgy 2011, 109, 116-124. [CrossRef]

69. Font, O.; Querol, X.; Juan, R.; Casado, R.; Ruiz, C.R.; López-Soler, Á.; Coca, P.; Peña, F.G. Recovery of gallium and vanadium from gasification fly ash. J. Hazard. Mater. 2007, 139, 413-423. [CrossRef]

70. Font, O.; Querol, X.; Huggins, F.E.; Chimenos, J.M.; Fernández, A.I.; Burgos, S.; Peña, F.G. Speciation of major and selected trace elements in IGCC fly ash. Fuel 2005, 84, 1364-1371. [CrossRef]

71. Li, T.; Wang, B.; Li, W.; Nie, J.; Song, Z.; Yang, W.; Ma, C.; Sun, L. Effect of occurrence modes of nickel and vanadium on gasification characteristics of petroleum coke. Fuel 2020, 263, 116686. [CrossRef]

72. Binnemans, K.; Jones, P.T.; Blanpain, B.; Van Gerven, T.; Yang, Y.; Walton, A.; Buchert, M. Recycling of Rare Earths: A Critical Review; Elsevier Ltd.: Amsterdam, The Netherlands, 2013; Volume 51, pp. 1-22.

73. Akcil, A.; Akhmadiyeva, N.; Abdulvaliyev, R.; Abhilash; Meshram, P. Overview On Extraction and Separation of Rare Earth Elements from Red Mud: Focus on Scandium. Miner. Process. Extr. Metall. Rev. 2018, 39, 145-151. [CrossRef]

74. Park, S.; Kim, M.; Lim, Y.; Yu, J.; Chen, S.; Woo, S.W.; Yoon, S.; Bae, S.; Kim, H.S. Characterization of rare earth elements present in coal ash by sequential extraction. J. Hazard. Mater. 2021, 402. [CrossRef]

75. Sarswat, P.K.; Leake, M.; Allen, L.; Free, M.L.; Hu, X.; Kim, D.; Noble, A.; Luttrell, G.H. Efficient recovery of rare earth elements from coal based resources: A bioleaching approach. Mater. Today Chem. 2020, 16, 100246. [CrossRef]

76. Dai, S.; Zhang, W.; Ward, C.R.; Seredin, V.V.; Hower, J.C.; Li, X.; Song, W.; Wang, X.; Kang, H.; Zheng, L.; et al. Mineralogical and geochemical anomalies of late Permian coals from the Fusui Coalfield, Guangxi Province, southern China: Influences of terrigenous materials and hydrothermal fluids. Int. J. Coal Geol. 2013, 105, 60-84. [CrossRef]

77. Zhang, W.; Noble, A. Mineralogy characterization and recovery of rare earth elements from the roof and floor materials of the Guxu coalfield. Fuel 2020, 270, 117533. [CrossRef]

78. Fu, X.; Wang, J.; Zeng, Y.; Tan, F.; He, J. Geochemistry and origin of rare earth elements (REEs) in the Shengli River oil shale, northern Tibet, China. Geochemistry 2011, 71, 21-30. [CrossRef]

79. Balaram, V. Rare earth elements: A review of applications, occurrence, exploration, analysis, recycling, and environmental impact. Geosci. Front. 2019, 10, 1285-1303. [CrossRef]

80. Eterigho-Ikelegbe, O.; Harrar, H.; Bada, S. Rare earth elements from coal and coal discard-A review. Miner. Eng. 2021, 173, 107187. [CrossRef]

81. Stuckman, M.Y.; Lopano, C.L.; Granite, E.J. Distribution and speciation of rare earth elements in coal combustion by-products via synchrotron microscopy and spectroscopy. Int. J. Coal Geol. 2018, 195, 125-138. [CrossRef]

82. Kolker, A.; Scott, C.; Hower, J.C.; Vazquez, J.A.; Lopano, C.L.; Dai, S. Distribution of rare earth elements in coal combustion fly ash, determined by SHRIMP-RG ion microprobe. Int. J. Coal Geol. 2017, 184, 1-10. [CrossRef]

83. Hood, M.M.; Taggart, R.K.; Smith, R.C.; Hsu-Kim, H.; Henke, K.R.; Graham, U.; Groppo, J.G.; Unrine, J.M.; Hower, J.C. Rare Earth Element Distribution in Fly Ash Derived from the Fire Clay Coal, Kentucky. Coal Combust. Gasif. Prod. 2017, 9, 22-33. [CrossRef]

84. Xiao-quan, S.; Wen, W.; Bei, W. Determination of gallium in coal and coal fly ash by electrothermal atomic absorption spectrometry using slurry sampling and nickel chemical modification. J. Anal. At. Spectrom. 1992, 7, 761. [CrossRef]

85. Goodarzi, F.; Huggins, F.E.; Sanei, H. Assessment of elements, speciation of As, Cr, Ni and emitted Hg for a Canadian power plant burning bituminous coal. Int. J. Coal Geol. 2008, 74, 1-12. [CrossRef]

86. Nazari, E.; Rashchi, F.; Saba, M.; Mirazimi, S.M.J. Simultaneous recovery of vanadium and nickel from power plant fly-ash: Optimization of parameters using response surface methodology. Waste Manag. 2014, 34, 2687-2696. [CrossRef] [PubMed]

87. Kuboňová, L.; Langová, Š.; Nowak, B.; Winter, F. Thermal and hydrometallurgical recovery methods of heavy metals from municipal solid waste fly ash. Waste Manag. 2013, 33, 2322-2327. [CrossRef]

88. Bielowicz, B. Selected harmful elements in polish lignite. Gospod. Surowcami Miner.—Miner. Resour. Manag. 2013, 29, 47-59. [CrossRef]

89. Riazi, M.R.; Gupta, R. Geochemistry of Coal: Occurrences and Environmental Impacts of Trace Elements. Coal Prod. Process. Technol. 2015, 65-92. [CrossRef] 